\title{
MISUSE OF CONFIDENTIAL INFORMATION
}

\author{
JACK PROTHROE*
}

\begin{abstract}
A continuing concern in the oil and gas business is the protection of secret information which may be fundamental to the success of a company in developing prospects. This paper discusses the extent to which the law will afford protection to such information, either through damage actions for its misuse or injunctions to restrain its use. The author discusses the circumstances under which information may become "confidential", and the guidelines developed by the courts in a number of different circumstances. Reference is made to the scope of 8. 7(e) of the Trade Marks Act; and the paper examines a number of practical considerations which may arise in attempting to protect confidential information through the courts.
\end{abstract}

\section{INTRODUCTION}

The discovery or development of novel intellectual concepts has created, in Anglo-American jurisprudence, two distinct property categories. First, in the case of patentable inventions, registerable trademarks, and industrial designs and copyrightable material, a public record is established. The proprietor derives his exclusive rights of ownership from the common and statute law surrounding this public recording of his novel intellectual concept. It is his obligation, during the term of his exclusivity, to protect his property rights by an action for damages or injunction. He is permitted, and indeed encouraged, to exploit his property by licencing procedures. The protecting state is presumed to benefit from the resulting increased economic activity. The second category of novel intellectual concept does not lend itself to protection by public record, because it does not fit any of the statutory definitions of registerable industrial or intellectual property. This is referred to as "confidential information". While common law and statute law have supported the first category, equity has been midwife for the second.

Having developed the novel intellectual concept (known as a "trade secret), often after considerable time, effort and experience, the proprietor of the trade secret is sometimes suddenly deprived of his property. As a result of disclosure by a trusted employee, or breach of a contract under which the trade secret has been communicated, the secret is no longer a secret. Its formerly exclusive possessor is left wondering whether he can obtain damages for the breach of contract or confidential relationship, delivery up of property wrongfully obtained through use of the trade secret, or, by injunction, restrain others from communicating the secret information or making use of it.

The improper use of communication of confidential information, unlike the infringement of patents, copyright and trade marks, usually gives rise to an action for injunction rather than damages. This is because confidential information depends, for its very existence, on its secrecy. Once it becomes public, its value is destroyed and the resulting damage is irreparable.

Should, however, the wrongdoer have acquired property rights through misuse of the confidential information, the courts may utilize the doctrine of constructive trust to compel the disgorging of wrongful profits to the plaintiff.

\footnotetext{
- Q.C., P.Eng., Patent Agent, Barrister and Solicitor, McLaws and Company, Calgary, Alberta.
} 
These remedies for the improper use or communication of secret or confidential information are the outgrowth of a competitive society, where business is complicated and increasingly dependent on costly and confidential technology. Corporations must act through agents and employees who are the stewards of this confidence. Business must have the unswerving loyalty of such agents; and the courts have been quick to recognize that any relaxation of the most rigorous standards would transform an orderly business society into a jungle. Judge Cardozo's language in 1928 in a confidential information case expresses this idea: ${ }^{1}$

A trustee (and by this is meant anyone occupying a fiduciary relation to another, whether as a trustee under an express trust, a partner, or agent or an employee) is held to something stricter than the morals of the market place. Not honesty alone, but the punctilio of an honor the most sensitive, is then the standard of behavior. As to this there has developed a tradition that is unbending and inveterate. Uncompromising rigidity has been the attitude of courts of equity when petitioned to undermine the rule of undivided loyalty by the disintegrating erosion of particular exceptions. . . . Only thus has the level of conduct for fiduciaries been kept at a level higher than that trodden by the crowd. It will not consciously be lowered by any judgment of this court.

Honesty alone is not enough; there must be, in addition, a meticulosity of honour. This is demonstrated by an examination of the case law. For over two hundred years, English courts have uniformly held, as a principle of law, that "it is certainly not agreeable to natural justice, that a stranger should reap the beneficial pecuniary produce of another man's work. Jure naturae aequum est, neminem cum alterius detrimento et junuria fieri locupletiorem."2

\section{WHEN DOES INFORMATION BECOME "CONFIDENTIAL"?}

"Confidential information", it would seem, must normally arise from a confidential relationship. The term "confidential relationship" is difficult to define precisely; it has been said that no language can precisely define the limits of the relationship. "A confidential relationship may exist although the relationship between the parties is not fiduciary." 3 It involves two elements: secrecy, and trust and confidence. Its essentials are a reposed confidence and the relationship of the disclosee to the discloser.

The term confidential relationship is very broad, and is not confined to any specific association of the parties. It exists where the relationship is such that the discloser is reasonably inspired with the confidence that the disclosee will act in good faith, based on trust, justifiably reposed. A confidential relationship exists where real confidence is found. ....

Once the "confidential relationship" is created, the disclosing of information under that confidence will make it "confidential information", providing it is not, of course, already in the public domain. Any fact which is not known to the public and which has been imparted in confidence may be characterized as confidential.

The courts have relied upon different grounds for exercising their jurisdiction in equity to restrain a breach of confidence; analogy tends to be the foundation of developing jurisprudence, but this has only created

1. Meinhard v. Salmon (1928) 249 N.Y. 458.

2. Miller v. Taylor (1769 4 Burr. 2303 at 2334; Nichrotherm Electriral v. Percy (1956) R.P.C. 272; Seager v. Copydex Ltd. [1962] 2 All E.R. 415, where Denning M.R. stated that the law on this subject does not depend on any implied contract.

3. Corpus Juris Secundum, 8. 15A at 355; Saltman Engineering Co. Ltd. v. Campbell Engineering Co. Ltd. [1963] 3 All E.R. 413.

4. Corpus Juris Secundum, 8. 15A at 357 . 
conceptual confusion. Much of the jurisprudential uncertainty in this area arises from the protean quality of confidential information.

"Information" is not like other choses in action, such as debt or copyright, which lend themselves more easily to a classical analysis in terms of property. It is often loosely said that a person "owns" information, 5 and it is true that confidential information has many of the traditional characteristics of property. There is no doubt, for example, that a secret can form the subject matter of a trust and that it can be assigned. But to categorize information as "property" does not satisfactorily solve the question: when should a defendant be deemed to be in breach of the plaintiff's confidence and be required to restore benefits through that breach?

Confidential information is conceptually very much sui generis. It is an intangible; and, consequently, it would be "wrong to confuse the physical records with (the information) itself . . . ; for if you put them on a duplicator and produce one hundred copies you have certainly not multiplied your asset in proportion."6

On more than one occasion Justice Holmes castigated the characterization of a "secret" as "property"; it was an "unanalyzed expression of certain secondary consequences of the primary fact that the law makes some rudimentary requirements of good faith". "No property theory can satisfactorily determine, even with the aid of equity, the question of the liability of the person who innocently exploits a secret. For example, there may be circumstances where it is just that a volunteer should be free of any liability to account for profits made through the use of confidential information. Conversely, it may not be difficult to imagine a case where even a bona fide purchaser ought to be enjoined, albeit on terms, from using information which he later learns was given him in breach of another's confidence.

Property, bailment, trust, fiduciary relationship and unjust enrichment have all been claimed, at one time or another, as the basis of judicial intervention. In Morison v. Moat, ${ }^{8}$ Turner V.C. stated:

In some cases it has been referred to property, in others to contract, and in others, again, it has been treated as founded upon trust or confidence-meaning, as I conceive it, that the court fastens the obligation on the conscience of the party, and enforces it against a party to whom a benefit is given, the obligation of performing a promise on faith of which the benefit has been conferred.

There would seem to be little doubt that this "founding on confidence" is the real foundation for the modern law. ${ }^{9}$ Recent Canadian jurisprudence has accepted without qualification that the basis of the restitutionary claim lies no longer in contract or property, but in a broad equitable principle of good faith, namely, that he "who has received information in confidence shall not take unfair advantage of it". ${ }^{10}$ For this reason a

5. There are many references in the reports to information as "property"; see, e.g., Dean v. Macdowell (1878) 8 Ch.D. 345 at 354, per Cotton L.J.; Aas v. Benham (1891) 2 Ch. 244 at 258, per Bowen L.J.; Phipps v. Boardman [1967] 2 A.C. 46 at 107, per Lord Hodson and at 115, per Lord Guest.

6. Rolls-Royce Ltd. v. Jeffery [1962] I All E.R. 801 at 805, per Lord Radcliffe.

7. I. Du Pont de Nemours Powder Co. v. Masland, (1917) 244 U.S. 100 at 102.

8. [1851] 20 L.J. Ch. 513 at 522.

9. Saltman Engineering Co. Ltd. et al. v. Campbell Engineering Co. Ltd. (1948) 65 R.P.C. 203 at 211, per Lord Greene M.R. At 213 he said: "If a defendant is proved to have used confidential information, directly or indirectly obtained from a plaintiff, without the consent, expressed or implied of the plaintiff, he will be guilty of an infringement of the plaintiff's rights."

10. Seager v. Copydex Led. [1967] 2 All E.R. 415 at 417, per Lord Denning M.R. See also Fraser v. Evans [1969] 1 All E.R. 8 at 11, per Lord Denning M.R. and Deeks v. Wells [1933] 1 D.L.R. 353. 
fiduciary, such as a trustee or a director, will be enjoined from using for his own benefit confidential information acquired qua fiduciary. So will a party who is in a confidential but not a strictly fiduciary relationship to another and who is given or learns information in the course of that relationship; no spouse or lover can exploit the verbal indiscretions of the double bed.

There is an increasing recognition in the cases that although information is not property in any normal sense, equity will restrain its transmission to another if in breach of some confidential relationship.

In the oil and gas industry, the dynamics of the business are based, in large measure, upon the secret nature of geological information. An exploration company will develop a geological concept, or, from a concept, develop a prospect. Land will then be sought to accommodate the prospect. But everything will depend on the entire activity being and remaining secret until property rights are fully vested; for if the "public", i.e. the rest of the industry, becomes prematurely privy to it, then the game is lost.

Such ideas are not capable of any registerable protection. As was pointed out by Riddell J.A. in Deeks v. Wells, ${ }^{11}$ there can be no copyright in ideas or information, and it is no infringement of copyright to adopt the ideas of another or to publish information derived from another. If, however, the idea or the information has been acquired under such circumstances that it would be a breach of confidence for it to be misused, the court will grant an injunction.12

It is immaterial that a right of this kind may give an employer greater rights than that given by copyright or patent. Of course, if confidential information has been reduced to writings, plans, maps, charts or drawings, then copyright is immediately involved; the Copyright Act, R.S.C. 1970, c. C-30, and the common law relating to breach of copyright can be invoked by an injured party. Non-copyrightable confidential information is known to the common law as "trade secrets". This paper will be principally concerned with the relationship of the law to these trade secrets.

The general nature of confidential information was discussed by Lord Greene M.R. in Saltman Engineering Co. Ltd. et al. v. Campbell Engineering Co. Ltd.13 Drawings of tools for the manufacture of leather punches were delivered to the defendants in order to manufacture certain tools. The defendants, contrary to their instructions, made a second set of drawings for their own use, utilizing some material derived from the original drawings. As Lord Greene M.R. pointed out, the defendants dispensed with the necessity of compiling the drawings, thus saving themselves a great deal of labour, calculation and careful draftsmanship. If they had taken the finished article (the leather punch, which they might have bought in a shop) and given it to an expert draftsman, he could have produced the necessary drawings for the manufacture of machine tools required for making the finished article. They saved themselves that trouble by obtaining the necessary information either from the original drawings or from the tools made in accordance with

11. [1933] 1 D.L.R. 353.

12. Exchange Telegraph Co. v. Gregory [1896] 1 Q.B. 147.

13. (1948) 65 R.P.C. 203. 
them. In holding that such conduct constituted a breach of confidence, Lord Greene M.R. observed at 215:

The information, to be confidential, must, I apprehend, apart from contract, have the necessary quality of confidence about it, namely, it must not be something which is purely public property and public knowledge. On the other hand, it is perfectly possible to have a confidential document, be it a formula, a plan, a sketch, or something of that kind, which is the result of work done by the maker upon materials which may be available for the use of anybody; but what makes it confidential is the fact that the maker of the document has used his brain and thus produced a result which can only be produced by somebody who goes through the same process.

In most cases, the identification of the confidential information is apparent, and the resulting benefit from its misuse will be equally apparent. But the benefit must be related directly to the disclosed confidential information, and not to public information towards which the employer, in an initiating sense, directed the defendant. Where a geologist is employed to study a certain area for the purpose of testifying as an expert witness in a case, and subsequently acquires for himself leases in a nearby area on the basis of public information he obtained during the study, no confidential relationship is created in respect of the nearby area. The circumstance of the employment may have been the factor which directed the geologist to the nearby area. But if he did not misuse information supplied in confidence by the employer, there is no wrongdoing. ${ }^{14}$ If, however, for his benefit he makes direct use of the confidential information (as distinct from the available public information), he will be compelled to disgorge the profits.15

A confidential relationship may expressly stipulate an obligation of confidence, but the obligation can also be implied. Thus, the relationship between an inventor and a voluntary disclosee will create an obligation of confidence preventing misuse by the disclosee of the unpatented invention. ${ }^{16}$

There has been, in both the United Kingdom and in Canada, a statutory attempt to enshire in legislation the common law rights of trade secrets. The Canadian Trade Marks Act, in addition to prohibiting the making of false or misleading statements, passing off and the use of false trading descriptions, provides that "no person shall ... . do any other act or adopt any other business practice contrary to honest industrial or commercial usage in Canada."17 Prima facie, the improper communication of confidential information and trade secrets will fall within that prohibition. There will be further reference to this legislation infra.

\section{THE FRAGILE NATURE OF CONFIDENTIAL INFORMATION}

The jurisdiction of the courts extends only to the communication of information that is demonstrably "confidential"; so courts will not constrain the use of information that is in the public domain.18 Matters do not become confidential merely because a contract between the parties states them to be so; they must bear the indicia of secrecy. A defendant is entitled to challenge the allegation that the information in question is or

\footnotetext{
14. Snakard v. McLaughlin et al., (1960) 351 P. 2nd 1013, 12 ?. \& G.R. 704 (Okla. S.C.).

15. Pre.Cam Exploration and Development Ltd. v. McTavish [1966] S.C.R. 551.

16. Pidot v. Zenith Radio 21 N.E. 2d 285; Breeze Corporation v. Hamilton Clamp \& Stampings Ltd. [1962] O.R. 29, 37 Can. Pat. R. 153; Seager v. Copydex Ltd. [1962] 2 All E.R. 415.

17. R.S.C. 1970, c. T-10, e. 7(e).

18. Canada Bonded Attorney \& Legal Directory Led. v. Leonard-Parmiter Led. (1918) 42 D.L.R. 342
} 
was at any relevant time secret and confidential. ${ }^{19}$ The courts will require, in some detail, information about the alleged secret information and the circumstances of the confidential relationship. ${ }^{20}$

In general, secret or confidential information remains exclusive only so long as secrecy is preserved.21 The onus is therefore on the owner of an alleged trade secret to show that it was known only to him and those of his employees in whom it was necessary to confide, ${ }^{22}$ and that it was improperly used. ${ }^{23}$

The owner of a trade secret, in contrast to a patent, has no right to exclude others from using it in all circumstances. If another person acquires the secret by honest means, he may use it.24 Protection will be given to a secret only where there is an attempt to use or disclose it in violation of a general duty of good faith (such as breach of contract or abuse of confidence). ${ }^{25}$ Information honestly and properly acquired may be dishonestly and improperly used.26 Although courts sometimes treat trade secrets as analogous to property, ${ }^{27}$ there is no right to restrain others from properly and independently endeavouring to discover the nature of trade secrets. Once discovered, they may be used, ${ }^{28}$ unless there are contractual rights, ${ }^{29}$ or information has been obtained under circumstances the court considers contrary to conscience. ${ }^{30} \mathrm{~A}$ trade secret may be contrasted to industrial property (for example, a patent right or copyright); with the trade secret, the discoverer has the full right to use it as soon as the secret is discovered, either by an examination of the product, or in any other honest way. ${ }^{31}$ The patent monopoly is a reward to the inventor. But the protection of a trade secret is not based on a policy of rewarding or otherwise encouraging the development of secret processes or devices. The protection is merely against breach of faith and reprehensible means of learning another's secret. For this limited protection it is not appropriate to require the novelty and invention which is a requisite of patentability. ${ }^{32}$

In order that a property right may inhere in a trade secret, it must be kept secret. This does not mean that a considerable number of persons may not know about it, as long as they received the information in confidence. On the other hand, if there has been a voluntary disclosure by the plaintiff, or if the facts pertaining to the matters are a subject of general knowledge in the industry, then any property right has evaporated.

As Justice Brandeis once said:33

19. Printers \& Finishers Ltd. v. Holloway Led. et al. (1961) R.P.C. 77.

20. $I d$.

21. R. L. Crain Led. v. Ashton [1949] O.R. 303; Robin-Nodwell Mfg. Ltd. v. Foremost Development Ltd. (1966) 52 Can. Pat. R. 244; O. Mustad \& Son v. Dosen (1963) R.P.C. 41, [1963] 3 All E.R. 416.

22. Robin-Nodwell Mfg. Ltd. v. Foremost Development Ltd. (1966) 52 Can. Pat. R. 244.

23. Stevens v. Robert Simpson Co. Ltd. (1964) 41 Can. Pat. R. 204.

24. R. L. Crain Ltd. v. Ashton [1949] O.R. 303; International Tools Ltd. v. Kollar [1966] 2 O.R. 201, injunction varied [1968] 1 O.R. 669.

25. Electric Reduction v. Crane (1961) 36 Can. Pat. R. 177.

26. International Tools Ltd. v. Kollar [1966] 2 O.R. 201, injunction varied [1968] 1 O.R. 669.

27. Green v. Folgham (1823) 1 Sim. \& St. 398; Exchange Telegraph Co. Led. v. Gregory \& Co. [1896] 1 Q.B. 147.

28. R. L. Crain Led. v. Ashton [1949] O.R. 303.

29. Coco v. A. N. Clark (Engineers) Led. (1969) R.P.C. 41 \& 47.

30. O. Mustad \& Son v. Dosen (1963) R.P.C. 41, [1963] 3 All E.R. 416.

31. R. L. Crain Led. v. Ashton, supra, n. 28; Fox, Canadian Patent Law and Practice (4th ed.) at 616.

32. 31 Restatement of Torts at 757.

33. International News Service v. Associated Press, (1918) 248 U.S. 215 at 250 , dissenting. 
The general rule of law is, that the noblest of human productions-knowledge, truths ascertained, conceptions, and ideas-become, after voluntary communications to others, free as the air to common use.

Relief from the seal of confidence will arise only when all of the confidential information properly falls into the public domain. If any such confidential information is not properly communicated to the public, the seal of confidence persists.

Confidential information may be transmitted to a limited class without destroying its value; thus, know-how can be communicated to or shared with others outside the manufacturer's own business, for example, under license. Conversely, the nature of confidential information is such that no one, save the person who imparted it, may realize for some time that it has been communicated in breach of confidence. For similar reasons it is not always easy to protect a purchaser of confidential information from the seller who subsequently sells the same information to another innocent third party.

In principle, there is no reason why an abstract idea should not be protected if the plaintiff can prove that it has not been publicly used before, that it was not "trivial tittle-tattle," 34 and that the defendant did not know of it before communication. Information may be confidential if the whole result is not known, even though its separate features or ingredients "have been published, or (are) capable of being ascertained by actual inspection by any member of the public." 35 It is the "whole result" which is vital, and if that "has not been achieved, . . . it will not fail to qualify (as confidential) by reason of the publication (of its separate features)".

The plaintiff must be prepared to show that he exercised reasonable security to maintain the trade secret; open or careless conditions surrounding the confidential information will work against the plaintiff. ${ }^{37}$ The issuance of a patent to the plaintiff on the subject matter of the trade secret will destroy it completely as a trade secret, ${ }^{38}$ for the essence of the patent system is full and complete disclosure by the patentee in exchange for a seventeen-year period of exclusivity.

\section{THE CATEGORIES OF MISUSE}

The case law of England, Canada and the United States suggests that the circumstances of misuse of confidential information can be divided into a number of categories: direct misuse by an employee, misuse by consultants, misuse by a stranger where disclosure is made in contemplation of a joint venture; and misuse by a partner or joint venturer where a member of the partnership seeks to profit individually from information belonging to the partnership or joint venture.

\section{(A) Misuse by an Employee}

Whether bound by express contract or not, an employee is not entitled to filch his employer's property, no matter what the form of the property. The employer's property must not be wrongfully used by the employee in

\footnotetext{
34. "Equity ought not to be invoked merely to protect trivial tittletattle, however confidential": Coco v. A. N. Clark (Engineers) Ltd. (1969) R.P.C. 41 at 48, per Megarry' J.

35. Ansell Rubber Co. Pty. Ltd. v. Allied Rubber Industries Ltd. (1967) Vict. L.R. 37 at 49, per Gowans J.

36. Id.

37. Robin-Nodwell Mfg. Ltd. v. Foremost Development Ltd, supra, n. 22 at 250.

38. Id. See also O. Mutatad \& Son v. Dosen (1963) R.P.C. 41.
} 
any way, but remains the property of the employer. ${ }^{39}$ The court interferes in such cases under the equitable doctrine of enforcing an obligation where a corresponding benefit has been received. In these cases the benefit is the original conferring of trust and confidence. ${ }^{40}$

It is immaterial whether or not the right accruing to the plaintiff arises from an express contract. Relationships such as those existing between master and servant rest on an implied contract. Where the court is satisfied that the confidential relationship exists, it infers a contract arising therefrom. This contract permits the exercise of the court's equitable jurisdiction to prevent what it considers a wrong. The court's equitable jurisdiction permits restraint of a breach of confidence independently of any legal right.

How far will the courts intervene where trade information is communicated by one occupying a confidential relationship? It must be ascertained whether or not the information is of a secret or confidential character, as opposed to ordinary trade or industrial information of the type gained by experience and skill. The publicity which surrounds modern life makes it more and more difficult to distinguish public knowledge from confidential information. Much depends upon whether the information was communicated in confidence, was secret, and was acquired by the servant as a necessary part of his duties, confidentially, or surreptitiously. On the other hand, was it the type of knowledge that an employee acquires in the ordinary course of his employment?

It must be recognized that no workman can be prevented (except by restrictive covenant) from carrying his ordinary skill and experience to another employer. Apart from secret and confidential knowledge, no employer can prevent his employee from making use (in the service of others or on his own behalf) of any knowledge or skill that the employee has gained in his service. ${ }^{41}$ It would obviously cause public injury if a man who has learned his trade in the workshops or laboratories.of any employer were unable to use that knowledge in any other employment. Therefore, any contract that attempts to prevent an employee making use of skill and knowledge that he has acquired in the business of the employer, as distinct from trade secrets or any such property, is unenforceable. ${ }^{42}$ This principle was restated by Milvain J. (as he then was) of the Alberta Supreme Court in Robin-Nodwell Manufacturing Ltd. v. Foremost Developments Ltd. and Nodwell. ${ }^{43}$

I think it is clear in the law that if an employee merely carries in his memory such material, that he is entitled to use his memory. In other words we cannot blot out a person's memory of matters unless it be that the knowledge he acquired was acquired on a confidential basis. Then that confidential or secret knowledge cannot be used by him even though it is carried away only in his memory.

Even though unrestricted in respect of space or time, a covenant in restraint of trade may be held to be reasonable, and therefore enforceable, if it relates to the use of a trade secret.44 A covenant reasonably necessary to protect an employer against communication of trade secrets will not be struck down merely because it also has the effect of protecting him

39. Morris v. Saxelby [1916] 1 A.C. 688.

40. International Tools Led. v: Kollar, supra, n. 26.

41. Robin-Nodwell Mfg. Ltd. v. Foremost Developments Ltd., supra, n. 22; Garbutt v. Henderson [1939] 3 W.W.R. 257.

42. R. L. Crain Led. v. Ashton, supra, n. 28; Sir W. C. Leng \& Co. Led. v. Andrews (1909) Ch. D. 763.

43. Supra, n. 22 at 249.

44. Morris v. Saxelby, supra, n. 39. 
against competition:45 but in the absence of such covenant no workman can be prevented from carrying with him the skill of his calling. To use the words of Asquith J. in B. O. Morris Ltd. v. F. Gilman (B.S.T.) Ltd. et $a l .0^{46}$ workmen will be restrained by injunction when they carry over to their new employers "more than what, on any view, they were entitled to carry over, namely their experience and skill". The parties to whom they communicate such confidential information will be restrained from making use of it.

There is, then, a fine distinction between a man using his mental equipment or knowledge and using his employer's secret. ${ }^{7}$ If the knowledge obtained by a servant includes a secret, the governing principles differ from where an injunction is sought to restrain him from using information and knowledge that he could not help acquiring while in his master's employment. This distinction appears in the judgment of Bennett J. in United Indigo Chemical Co. Ltd. v. Robinson, ${ }^{48}$ the judgment of the Court of Appeal in Rex Co. et al. v. Muirhead, 49 and was shortly stated by Evershed M.R. in Stevenson Jordan \& Harrison Ltd. v. MacDonald \& Evans: 50

If I understand the use of language correctly, 'know-how' seems to indicate something quite essentially different from secret and confidential information. It indicates the way in which a skilled man does his job, and is an expression of his individual skill and experiences. If I may take an example, a man may in writing make a fairly detailed description of how to produce a particular result by a series of chemical processes or reactions; but as all the world knows in practice the best result is obtained not by merely following all the directions in the book, but by the way in which the experienced man carries out those directions. This knowledge, I should have thought, was a quality or capability resulting from experience, which a man is entitled to use for his own purposes and for his own advancement in his trade or profession.

Where the information is not communicated to the servant by the employer, where it is not of a confidential character, and where it is obtained honestly and openly rather than surreptitiously, the employer cannot, apart from contract, prevent the employee from communicating it. Where it is, to use the words of Morton J. in $E$. Worsley \& Co. v. Coopersi "information which a determined and persistent trade rival, with sufficient skill and knowledge of the ... business, could have ascertained at the cost of considerable inquiries of considerable length", then it is not entitled to protection as a trade secret. There is, therefore, an essential difference between trade secrets and trade information. The former will be protected against use or disclosure by an employee, while the latter will not. This principle has been well settled by a line of authorities.52

Most of the leading cases arising in the resource industries are found in the American reports. But the principles are universally found in Anglo-American jurisprudence and similar results can be anticipated from Canadian courts.

An early case concerning the use by an employee of geological

45. Id.

46. (1943) 60 R.P.C. 20 at 24.

47. R. L. Crain Led. v. Ashton, supre, n. 28.

48. (1932) 49 R.P.C. 178.

49. (1927) 44 R.P.C. 38.

50. (1952) 69 R.P.C. 10 at 15.

51. [1939] 1 All E.R. 290 at 308.

52. R. L. Crain Led. v. Aohton, supra, n. 28; Canadian Aero Services v. O'Malley (1969) 61 Can. Pat. R. 1. 
information is Pratt v. Shell, 53 where a geologist employed by Shell was given the responsibility of correlating geological work in a specific area and making recommendations for the acquisition of leases and drilling of wells. The geologist acquired leases for himself and some associates. He defended a constructive trust action on the basis that Shell had suffered no monetary loss by his actions. The court rejected this defence. The court conceded that an employee might act to his own profit outside the area of interest or scope of business of the employer without having to account to his employer. But here the evidence was clear that his impugned activities were in his employer's backyard, and the geologist-employee had made use of information acquired during his employment. The defendant was in a position of high trust and confidence, not merely because of his access to geological information, but also because of his ability to use it and arrive at intelligent conclusions. He was found to have divulged his employer's plans for exploration and development to third parties so that they might acquire interests and carry him for a share. The employee argued at length that Shell had either abandoned its leases in the area where he purchased or had never acquired any, and that therefore the purchases were not competitive. The fallacy in that argument was that it rested upon the concept that actual damages must be shown. The court said ". . a fiduciary relationship and a breach of duty where it exists warrants the imposition of a constructive trust where ... (the defendant)... cannot in good conscience retain this beneficial interest, without regard to the question of pecuniary damage."54 The court specifically declared that an employee would not be prohibited from trafficking to his own advantage outside the scope of his employer's business.

Shell again found itself in conflict with one of its geological employees in the later case of Hunter v. Shell. ${ }^{55}$ The defendant was in charge of Shell's interests in the Gulf Coast area. In the course of his employment he received geological and geophysical information of a highly confidential nature, which he passed on to others so that they might acquire property interests for their mutual benefit. Shell had a specific rule prohibiting any trafficking by its employees in mineral interests. After a five month trial, affirmed on appeal, the Appellate Court made these remarks:56

An agent may trade for his own benefit outside the scope of his principal's business without being accountable for the profits realized. But he is forbidden to deal with a subject matter of the agency, or to use for his own advantage information acquired while acting within the scope of the agency. Nor may an agent put himself in a position in which his personal interests may come into conflict with his duty to his principal, or which may afford him an opportunity to subordinate the interests of his employer to his own individual benefit while discharging his duties. Such conduct is not only morally wrong, it is contrary to public policy. When property has thus been wrongfully acquired, equity converts the holder into a trustee, and compels him to account for all gains from such conduct.

In Cheuron v. Tlapek, ${ }^{57}$ the defendant geologist tried to clear himself by first resigning his employment, and then acquiring the property interests. He had laboriously studied a certain prospective formation, and devised

53. (1938) 100 F. 2d 833.

54. Id. at 839 .

55. (1962) 198 F. 2d 485.

56. Id. at 488-9.

57. (1967) 26 O. \& G.R. 301 . 
a unique plan for its development. When the plaintiffs failed to act promptly on the plan, he resigned, duplicated the plan and secured property rights within the formation for his own account, along with partners. Chevron claimed constructive trust. The court found in its favour, holding that this fiduciary obligation is not discharged by termination, for whatever reason, of the employment. One element of the defence was that the defendant took no maps or other tangible items of personal property from the plaintiff's files and records, but simply reconstructed maps "in his head". It was argued that what the defendant could carry away in his head was his own property to use as he saw fit. The court rejected this, and held that the unique theory or concept which he conceived while in the employ of the plaintiff was as much its property and confidential information as any physical data, such as maps or drill cores.

\section{"Corporate Opportunity" Cases}

A related type of case arises where officers or directors of companies, in the course of discharge of office, become aware of a business opportunity available to their company and take personal advantage of it. This is a clear misuse of confidential information (that is, knowledge of the existence of the business opportunity). It must only be established that this disclosure was made to the officer or director in his fiduciary capacity.

In Canadian Aero Service Ltd. v. O'Malley et al.58 the Supreme Court of Canada, per Laskin J. (now C.J.C.), expanded upon what he describes as "the rigorous standard of behaviour enforced against" the "top management" of a corporate body in the type of situation that was before the court. In Canadian Aero Service Ltd. v. O'Malley et al., the defendants $O^{\prime} M a l l e y$ and Zarzycki held top management positions with the plaintiff company. While so employed, they incorporated the defendant company, and planned to utilize a corporate opportunity (in which the plaintiff had a prior and a continuing interest) for their company. They submitted their resignations to the plaintiff corporation. Then, through the defendant company, they pursued and obtained a contract which they, as senior officers, had actively sought for the benefit of the plaintiff. This was a breach of a fiduciary duty owed by them to the plaintiff corporation. In awarding damages against the defendants O'Malley and Zarzycki and their company, Laskin J. said:59

It follows that O'Malley and Zarzycki stood in a fiduciary relationship to the plaintiff, which in its generality betokens loyalty, good faith and avoidance of a conflict of duty and self-interest. Descending from the generality, the fiduciary relationship goes at least this far: a director or a senior officer like O'Malley or Zarzycki is precluded from obtaining for himself, either secretly or without the approval of the company (which would have to be properly manifested upon full disclosure of the facts), any property or business advantage either belonging to the company or for which it has been negotiating; and especially is this so where the director or officer is a participant in the negotiations on behalf of the company. An examination of the case law in this court and in the courts of other like jurisdictions on the fiduciary duties of directors and senior officers shows the pervasiveness of a strict ethic in this area of the law. In my opinion, this ethic disqualifies a director or senior officer from usurping for himself or diverting to another person or company with whom or with which he is associated a maturing business opportunity which his company is actively pursuing; he is also precluded from so acting even after his resignation where the resignation may fairly be said to have

58. (1973) 40 D.L.R. (3d) 371; [1974] S.C.R. 592 at 613-4.

59. Canadian Aero. Services Led. v. O'Malley et al. [1974] S.C.R. 592 at 606. 
been prompted or influenced by a wish to acquire for himself the opportunity sought by the company, or where it was his position with the company rather than a fresh initiative that led him to the opportunity which he later acquired.

Professor R. J. Roberts, in a thoughtful analysis of the Canadian Aero case $^{, 00}$ has criticized the judgment of the Supreme Court for failing to recognize the distinction between liability for breach of a fiduciary relationship (which relationship had terminated in Canadian Aero upon the resignations of the two defendant director-employees before their having put the "corporate opportunity" to improper use), and liability for misuse of confidential information acquired in circumstances of confidence, i.e. while they were director-employees. Few would dispute the justice of the result in Canadian Aero; but the case remains a disappointment, as Professor Roberts concluded, because the Supreme Court declined an opportunity to untangle the problems of confidential information and fiduciary obligations. The court, it is submitted, should have relied on the relationship between the employer and the employeedirectors existing at the time the confidential information was imparted as being conclusive evidence of the fact that the employee-director was then in the confidence of his principal; subsequent resignation would then not avail the defendant.

\section{(B) Misuse by Consultants}

Cases involving strictly employer-employee relationship do not present as many problems as cases involving specially hired personnel and third persons. The leading Canadian case involving resource industry consultants is the Supreme Court of Canada decision in Pre-Cam Exploration $\&$ Development Ltd., and Murtack v. McTavish et al. ${ }^{61}$ The plaintiff Murtack retained Pre-Cam to carry on exploratory work on some fifteen specific mineral claims recorded in the plaintiff's name. Pre-Cam was instructed to ascertain the size and location of mineralization by magnetometer and to stake any additional claims necessary to bring the entire zone under the plaintiff's control. Pre-Cam hired the defendant McTavish at a monthly salary as a magnetometer operator for this purpose. While thus engaged, McTavish discovered that the mineralized zone extended northeast of the plaintiff's stakings. Consequently, he decided to stake that ground in his own right. Over his Christmas holiday, McTavish interested other defendants in his venture. With their financial support, he returned to the area, called en route to the offices of Pre-Cam to collect his pay, and resigned from his employment. It is significant to note the absence of contract between the plaintiff and McTavish: the plaintiff had only contracted with Pre-Cam, McTavish's employer. The plaintiffs successfully sued for a declaration that these claims as staked by McTavish in his own name were held in trust for Murtack; an order was made transferring the claims to the plaintiff. Judson J. said at 555:

Without the information acquired during the course of his employment, McTavish would not have staked the adjoining claims. This was highly confidential information and the purpose for which it was being sought was obvious - the acquisition of other connected claims which would be of advantage to the existing claims. Neither Pre-Cam nor McTavish, its servant, could acquire these connected claims against the interest of Murtack. Contrary to the majority opinion in the Court of Appeal, I think that it was a term of his employment, which McTavish on the facts of this case understood, that he 
could not use this information for his own advantage. The use of the term "fraud" by the learned Chief Justice at trial was fully warranted. The severance of his employment on December 27 th was an empty formality which could not improve his position. I do not mean by this that a simple-minded person with his own ideas of common honesty could do this sort of thing without having to answer. The constructive trust is imposed in a case of this kind because of the mere use of confidential information for private advantage against the interest of the person who made the acquisition of the information possible.

The U.S. case books are replete with authorities to similar effect. In Barnsdall $v$. Willis, ${ }^{62}$ the defendant was an independent lease broker employed to block a specific area for Barnsdall. In the center of the block was a tract which had been under lease to another oil company. Accordingly, Willis received no specific instructions with respect to this tract. Upon learning that it had been given up, he acquired a lease on it in the name of his brother-in-law. Later, Barnsdall asked Willis to attempt to get an assignment of the lease. He did so, at a very substantial profit to himself, in addition to his usual commission from Barnsdall. Upon learning of the facts, Barnsdall sued to recover both the profit and the commission. The lower court held that Willis was not an employee of Barnsdall, but an agent for a specific purpose; since that purpose did not include purchasing that particular lease at that time, Willis acted within his rights. On appeal, the court stated that the concealment of the broker's connection with the lease was to his discredit. However, if he had no confidential information concerning the value and desirability of the particular lease at the time he acquired it, then the concealment of the purchase alone would not make him a constructive trustee of Barnsdall. The controlling factor in the case, said the court, was whether Willis had obtained confidential information by virtue of his relationship as lease broker, and whether or not he took advantage of such information to his own benefit and to the detriment of Barnsdall. Barnsdall did not contend that its shooting was made available to the defendant, but urged that the confidential information was the advice that it was blocking the area and a test well might be drilled. The outline of the area certainly was known, and the lease in question was in the center. As a result, it was held that Willis took advantage of confidential information which he would not have received but for his employment. Such information was used for his own enrichment, and his personal position conflicted with that of his employer. Consequently, a constructive trust was imposed.

A recent Canadian case is similar in its facts, but had the opposite result. In Guyer Oil Company Ltd. et al. v. Fulton ${ }^{63}$ the defendant consulting geologist who had sat wells and performed other services as consultant for the plaintiff personally secured oil and gas rights in the area. When challenged by the plaintiff, which claimed constructive trust, the defendant successfully maintained that he had only used information previously known to him or in the public domain, and that any information coming to him as a result of having consulted for the plaintiff was insignificant. While the plaintiff's activities may have pointed him in the direction in which he acquired property rights, the plaintiff's confidential information was not established as the effective cause of such acquisition. The court stated:84

62. (1946) 152 F. 2d 824; 173 F. $2 d 979$.

63. (1973) 1 W.W.R. 97.

64. Id. at 120 . 
In my opinion, the relationship between John Fulton and his clients in the Dodsland field imposed on him certain duties, one of which required him to maintain the confidentiality of all confidential information which he obtained in the course of his employment by them. This could be the only duty devolving on John Fulton which is relevant to this action. However, that duty ceased, in my opinion, as soon as that information regularly reached the public domain.

A recent U.S. case is Consolidated Oil \& Gas, Inc. v. Ryan, ${ }^{65}$ which illustrates the principle that where the negotiating parties, although not in a fiduciary relationship, are not in positions of equal strength and accordingly not dealing at arm's length, equity imposes an obligation on the dominant party to make full disclosure if he speaks at all.

The defendant consulting geologist had occasionally been employed by the plaintiff and had knowledge of a gas discovery in the area of a lease owned by the plaintiff. He negotiated to purchase the lease from the plaintiff while concealing and misrepresenting its value. The court found that the plaintiff had justifiably relied on the defendant, because of its trust and confidence in him; it was held that in these circumstances, "... in which one party knows the other is relying upon the truthfulness and there being full disclosure of information ...",68 the defendant is required to make full disclosure, if he speaks at all. The defendant had attempted to rely on the proposition that, as a general rule, there is no duty as between vendor and purchaser to disclose any information affecting the value of property in an arm's length transaction. While not disputing this as a valid principle of law, the court held that the circumstances were not arm's length, and that "when specific inquiry is made of a party who possesses special knowledge and he makes a partial disclosure intending that the other party shall rely upon it, and thus induces the other party to be misled", ${ }^{67}$ equity will interfere.

This rule is particularly applicable to relationships between consultants and clients, where the existence of one dominant party in the relationship is almost inevitable.

In $55 \mathrm{Am}$. Jur., Vendor \& Purchaser, s. 88 at 563, the following statement is made with regard to the circumstances (in addition to technical fiduciary relationships) that give rise to a duty to make truthful and full disclosures:

While as a general rule a prospective purchaser of land does not owe the vendor any positive duty to inform him of facts or conditions affecting the value of the land, or to acquaint him with circumstances that may make the property desirable or advantageous to the purchaser, this rule does not apply where there exists some fiduciary relation between the vendor and the purchaser; and circumstances other than a fiduciary relationship may justify a vendor who was totally ignorant of the value of the land in relying on the purchaser's statements, especially when accompanied by representations as to its condition, and the like. The fact that the purchaser has special information regarding facts enhancing the ordinary value of land places him under a legal obligation to do no act or make any representation calculated to mislead the owner in the belief that there was no special condition affecting the value. The purchaser must make no statement calculated to mislead the vendor or prevent an examination of the property involved; he is not permitted to say or do anything to throw the vendor off his guard in order to obtain the property from him. It has been said that the least degree of misrepresentation constitutes very potent evidence of fraud under such circumstances.

Partial disclosure can mislead, when no disclosure at all would not

65. (1966) 250 F. Supp. 600; 24 O. \& G.R. 237.

66. 24 O. \& G.R. at 243 .

67. Id. 
have created any false impression. A concise treatment of this principle is found in 55 Am. Jur., 8. 88, at 564:

Fraud may be predicated upon an equivocal, evasive, or misleading answer calculated to convey a false impression even though it may be literally true as far as it goes. A partial and fragmentary disclosure accompanied by wilful concealment of material and qualifying facts is not a true statement and is often as much a fraud as an actual representation. In such cases if the vendor does in fact rely upon the information given him by the purchaser which is false or misleading, equity will grant him relief from the contract that he was thus induced to enter into.

\section{(C) Misuse by a Stranger}

The foregoing cases, where there is a clear confidential relationship, have caused the courts no great difficulty. They have been ready to grant an injunction and also to strip the defendant of his unjust enrichment. But information may have been given in confidence to a person who is not, at that time, in a fiduciary or confidential relationship to the plaintiff. That confidence is later breached. In recent years the courts have been confronted with this problem, and have formulated an equitable principle which is sufficiently generous to meet every case of breach of confidence. The principle is that an equitable obligation of confidence may arise from the mere receipt of information in the knowledge that it was confidential, and that: ${ }^{88}$

the law on this subject . . . depends on the broad principle of equity that he who has received information in confidence shall not make use of it to the prejudice of him who have it without obtaining his consent.

Circumstances frequently arise in commercial dealings where disclosure of secret information is made by one person to another in prospect of a deal to be made, and without any specific undertaking by the disclosee with regard to his subsequent use of the information. A fiduciary relationship, which would impose the stringent restraints of equity on the misuse of the information, does not exist. Nonetheless, equity finds a way to intervene. In fact, trade secrets cases often prevent continued use of a trade secret communicated to a prospective agent or corporation on the understanding, express or implied, of contemplated joint venture. If information is given by one person to another in circumstances that make that information confidential, then the second person is disentitled to use it for purposes of competitive trade. There need not be a contractual relationship. The general basis of a damage or restraint action for divulging trade secrets is that a cause of action exists where confidence is abused. ${ }^{69}$ The court interferes in such cases based on the equitable doctrine that an obligation may be enforced where a corresponding benefit has been received; the benefit in these cases is the original conferring of trust and confidence. ${ }^{70}$

Equity has thus intervened where an inventor voluntarily disclosed an unpatented invention to a proposed licensee. ${ }^{71} \mathrm{By}$ analogy, the disclosure to a stranger of secret information relating to an oil or gas prospect would impose similar obligations. This was the result in Ballard v. Claude Drilling Co. ${ }^{72}$ where A offered B an opportunity in a farmin being

68. Seager v. Copydex Ltd. [1967] 2 All E.R. 415 at 417.

69. Laidlaw v. Lear (1898) 30 D.R. 46.

70. International Tools Ltd. v. Kollar, supra, n. 26.

71. Pidot v. Zenith Radio 21 N.E. (2d) 285.

72. (1939) 88 P. 2d 102. 
negotiated. B went behind A's back, took the deal directly, and drilled a successful well. B was held to be a constructive trustee for A.

The position of the third party stranger, who gains his knowledge of confidential information through the defecting of an upstream fiduciary, will be considered later. ${ }^{73}$

\section{Industrial Espionage}

Consider now the position of the industrial spy, who obtains confidential information by covert or reprehensible means. This "stranger" has not been entrusted with any confidential information, and did not acquire it from a confidant. He has, for example, acquired it by the use of an electronic "bug".

In equity, a defendant who has taken care not to enter into any relationship with the plaintiff, and who has obtained confidential information by reprehensible means, should be in no better position than a defendant who is given and deliberately breaches the plaintiff's confidence.

The formula, "reprehensible means", ${ }^{74}$ should be sufficiently flexible to enable the court to balance the equities of each case. It is submitted that an obligation should be imposed upon the defendant who bugs a telephone; but there should be no obligation on someone who overhears a confidential conversation (even, perhaps, if he positions himself to overhear). A plaintiff who does not take reasonable steps to protect the secrecy of information should not be able to claim that another has breached his confidence. ${ }^{75}$

An oil scout who observes, from afar, the competitor's drilling rig on a "tight hole", counting the stands of drill pipe in order to determine drilling depth, would seem to be in a different position than the scout who buys the information from a subverted driller.

The writer is unaware of any English or Canadian authority holding that a defendant who uses reprehensible means to obtain confidential information is liable in equity to make restitution. ${ }^{76}$ The courts will probably not be reluctant to impose such a liability. It should be irrelevant that the defendant may also commit a tort in acquiring that information, for example, by placing a bug upon the plaintiff's premises. Indeed, in many cases, he may be sufficiently ingenious to purloin confidential information without committing a tortious act. So, he may use a telephoto lens situated on his own property to photograph the plaintiff's documents. Then, even if the courts were to accept Weir's generous principle? that it is "tortious, intentionally to damage another

73. Infra at 277.

74. Restatement of Torts at 7.

75. Cf. the language of Justice Brennan, dissenting, in Lopez v. United States, (1963) 373 U.S. 427 at 450: "It is not an undue risk to ... compel (people) to uBe discretion in choosing their auditors, to make damaging disclosures only to persons whose character and motives may be trusted. But the risk which . . . today's decision impose(s) is of a different order. It is a risk that third parties, whether mechanical auditors . . . or human transcribers of mechanical transmisaions ... third parties who cannot be shut out of a conversation as conventional eavesdroppers can be, merely by a lowering of voices, or withdrawing to a private place-may give independent evidence of any conversation. There is only one way to guard against such a riok, and that is to keep one's mouth shut on all occasions."

76. The defendant who doee not use reprehensible means to acquire information may, therefore, be in a better position than he who, in good faith, buys information from the plaintiffe confidant. At first sight this may appear to be an odd conclusion. But the plaintiff who obtains relief against a bona fide purchaser will do 80 only on the terms that he pays back the purchase price; and it is proper that persons who claim from, through or under the plaintiff's confidant should be in a different position from the defendant who obtains confidential information by chance.

77. Wier, Chaos or Cosmos? (1964) Camb. L.J. 225 at 226. 
by means of an act which the actor was not at liberty to commit," he would escape tortious liability. Without the aid of equity, the law of tort may not be sufficiently flexible to combat all the scientific devices and techniques which the moderm industrial spy has at his disposal. Equity, to borrow a metaphor, should not be past the age of child-bearing.

\section{(D) Misuse by a Partner or Joint Venturer}

Where one of the partners in a joint venture seeks to profit individually from information belonging to the partnership, the consequences of the misuse of confidential information are predictable. The rule was succinctly stated by Cardozo J. in Meinhard v. Salmon:78 "Joint venturers, like co-partners, owe to one another, while the enterprise continues, the duty of the finest loyalty."79

In expanding on the rigors of the rule, Cardozo J. stated:80

Salmon had put himself in a position in which thought of self was to be renounced, however hard the abnegation. He was more than a coadventurer. He was a managing coadventurer... . For him and for those like him, the rule of undivided loyalty is relentless and supreme.

The rule is based on the existence of a fiduciary relationship arising out of the partnership. One example is where A offered B an opportunity to join in drilling a well on a farmout; $B$ went behind A's back, took the deal directly and drilled the well; $B$ was made to disgorge the profits. ${ }^{81}$ In Board of Trade of Chicago v. Christie Grain \& Stock Co., ${ }^{82}$ where the defendant gave others confidential information acquired under a partnership with plaintiff, the defendant was made to account. In Foucheck v. Janicek, ${ }^{83}$ the court said:

Information belongs to a partnership in the sense of property in which it has a valuable right, if it is of the character which might be employed to the partnership's advantage.

Such information cannot be used by one partner for his private gain.

Adjacent owners having divided (as distinct from undivided) interests in a lease have been held not to be fiduciaries (Luton v. Martin); ${ }^{84}$ but quaere whether, had they held undivided interests, the result might have been otherwise.85

However, rigid adherence to the strict standards of accountability required of trusted employees would create impossible burdens in circumstances of the complex multi-party joint venture, an increasingly popular structure for enterprises where single parties are capacity-limited. Normally, language in the joint venture agreement will contractually define the responsibilities, inter se, of the co-venturers; and the variable latitude of equity in the activities of the fiduciary is examined, infra at p. 276.

\section{SECTION 7(e) OF THE TRADE MARKS ACT}

The Federal Government, unwittingly or otherwise, entered the field of the corporate conscience in this area, utilizing the improbable tool of the

78. Supra, n. 1.

79. Quoted with approval by the Sagkatchewan Court of King'B Bench in Natural Sodium Products Ltd. v. Holland (1946) I W.W.R. 605 at 611.

80. (1928) 249 N.Y. 458 at 471.

81. Ballard v. Claude Drilling Co., supra, n. 72.

82. (1904) 198 U.S. 236.

83. (1950) 225 P. 2d 783, 791.

84. (1959) 337 P. 2d 442, 10 O. \& G.R. 292.

85. See Smith v. Bolin (1953) 3 O. \& G.R. 96 (Texas C.A.). 
Trade Marks Act, R.S.C. 1970 c. T-10 (formerly known as the Unfair Competition Act) Section 7(e) of the present legislation reads:

s. 7 No person shall do any other act or adopt any other business practice contrary to honest industrial and commercial usage in Canada.

The Chief Justice of the Federal Court of Appeal, Federal Court of Canada interpreted this section in Vapor Canada Ltd. v. MacDonald (1972) 8 Can. Pat. R. (2d) 15 at 23:

In the absence of some convincing reasoning or authoritative or persuasive authority to the contrary, I am of the opinion that the corporate appellant contravened $\mathrm{B}$. 7(e) when it used in its business information obtained for it from a former employee or a competitor in breach of the former employee's confidential relationship with that competitor. I am further of opinion that the appellant MacDonald contravened 8 . 7(e) when, as the directing mind of the corporate appellant, he caused the corporate appellant to be in contravention of that provision.

The Chief Justice went on to say: 86

In my view, s. 7(e) applied to the obtaining and use of documents that have been wrongfully purloined from a competitor in exactly the same way as it applied to the obtaining and use of confidential information. The wording and spirit of 8. 7(e) apply equally to the one as to the other.

The case was appealed to the Supreme Court of Canada as to the constitutional validity of 8 . 7(e). The eight judges who sat on the case unanimously held that it was ultra vires the Federal Parliament, since it dealt with "Property and civil rights", a subject of provincial jurisdiction: 87

There is here merely an alleged breach of contract by a former employee, a breach of confidence and misappropriation of confidential information. It is outside of federal competency to make this the subject of a statutory course of action.

The court held, however, that the section could apply to cases clearly involving heads of federal power, such as the regulation of trade and commerce, or patents, copyright and trade marks. Therefore, only the shadow of section $7(e)$ now remains.

\section{PRACTICE CONSIDERATIONS}

\section{(A) Injunction: Its Availability, Use and Limitations}

An injunction will not be granted restraining the communication of a trade secret unless the court is satisfied that there is a real danger that the defendant intends to communicate the secret or to use it to the irreparable detriment of the plaintiff. On a motion for an injunction the defendant may be ordered to deliver up all documents and extracts in his possession containing the confidential information. The motion may be heard in camera in order to protect the secret information from public disclosure. ${ }^{88}$ The courts will be reluctant to enjoin even a dishonest third party defendant who can establish that the information contributed only minimally to the development of his property. De minimus non curat lex.

In most jurisdictions where injunctions are available, such relief will only be granted on interlocutory motion (as distinct from the trial of the issue) if the plaintiff undertakes to accept responsibility for the consequences of its wrongful issuance. Thus, a difficult decision faces the 
pursuing oil company plaintiff where an employee has apparently disclosed prospect secrets to a third party competitor, and the competitor is about to drill the prospect. Should the company apply for an interim injunction to restrain the third party drilling, and be fixed with the monetary consequences if the interim injunction is not maintained after a trial on the merits? Or should it allow the drilling to proceed, knowing that the rest of the industry (which is beyond its reach) will certainly be informed, through its scouts, as to the success of the drilling? If the plaintiff is reluctant to accept the consequences, the game may be lost to the third party predators waiting for the spoils to fall their way.

\section{(B) The Constructive Trust}

Courts of equity have recognized the shortcomings of legal remedies such as damages or the right to repudiate the employment contract of an unfaithful servant. They have adopted a far more effective remedy in the "constructive trust". Since the wrongdoer may not profit from a breach of trust, he is considered a constructive trustee as to that profit, for the benefit of his cestui que trust. In II White and Tudor's Leading Cases in Equity (7th ed. 1897) 695, the scope of the rule is stated in these terms:

Whenever a person clothed with a fiduciary or quasi fiduciary character or position gains some personal advantage by availing himself of such character or position, a constructive trust is raised by Courts of Equity, such person becomes a constructive trustee, and the advantage gained must be held by him for the benefit of his cestui que trust.

A constructive trust has been defined by Judge Cardozo, one of the great American Equity jurists, as the formula through which the conscience of equity finds expression. The purpose of constructive trusts is to deny the fruits of conduct which may be classified as "fraudulent or unfair and unconscionable."89 In Powell v. Chastain, 318 P. 2 d 859 (Okla.), it was held at 862:

Constructive trusts are those raised by equity for the purpose of working out right and justice, where there was no intention of the party to create such relation, and often directly contrary to the intention of the one holding the legal title. All instances of constructive trusts may be referred to what equity denominates "fraud", either actual or constructive, including omissions in violation of fiduciary obligations. If one obtains the legal title of property by fraud or by violation of confidence or fiduciary relationship, or in any other unconscientious manner, so that he cannot equitably retain the property which really belongs to another, equity carries out its theory of a double ownership, equitable and legal, by imposing a constructive trust upon the property in favor of the one who is in good conscience entitled to it, and who is considered in equity as the beneficial owner.

Such trusts are outside the operation of the Statute of Frauds. ${ }^{90}$

When property has been acquired in such circumstances that the holder of the legal title may not in good conscience retain the beneficial interest, equity converts him into a trustee. A court of equity will not permit either an unfaithful fiduciary, or those in league with him, to

89. See 89 Corpus Juris Secundum, Trusts, 8. 139 et seq. at 1015.

90. With respect to the question of whether the Statute of Frauds may be avoided by the application of the constructive trugt theory, where only a verbal promise to acquire land is involved, the following quotation from Scott on Trusts, 8.40 at 234 would seem applicable: ". . . the courts have evolved certain forms of expression which can bo called into use to reach whatever result they feel ought to be reached, that result depending upon considerations of policy which are frequently left unexpressed. Whenever they are desirous of giving relief in opite of the statute, they emphasize the handships which would result from the application of the statute; they denounce the party who relies upon the statute; they speak of fraud and say that the statute was enacted to prevent fraud and not to promote fraud. On the other hand, if it is felt that the transaction should not be upheld in spite of the resulting hardship, it is easy for them to place the responsibility upon the legislature and to refuse to 'fly in the teeth of the statute'." 
appropriate to their personal profit the property of the principal. The basis of this relief appears to be the equitable principle forbidding unjust enrichment. This principle has been applied to the wrongful disclosure of trade secrets, to administrators of estates and receivers and trustees in bankruptcy seeking to acquire property under their administration, to corporate officers seeking to benefit by intimate knowledge of their company plans, and to joint ventures where one of the partnership seeks to profit individually by information belonging to the partnership. The policy of the rule is to close the door against temptation.

The United States Supreme Court has succinctly explained the rule in these terms: $: 1$

This is not because such interests are always corrupt, but because they are always corrupting. By its exclusion of the trustee from any personal interest, it seeks to avoid ... delicate inquiries into the conduct of the ... (trustee) by exacting from them forbearance of all opportunities to advance self-interest that might bring the disinterestedness of their administration into question ... . equity has sought to limit difficult and delicate fact-finding tasks concerning its own trustees by precluding such transactions for the reason that their effect is often difficult to trace, and the prohibition is not merely against injuring the estate-it is against profiting out of the position of trust.

Thus, it is no answer to a petition for a declaration of trust that the trustee only did what anyone else could have done readily; he may be the only person in the world who is precluded from the opportunity, but such is the rigorous code of equity.

\section{(C) Degree of Proof}

The onus upon the plaintiff in establishing all of the necessary ingredients of the confidential relationship and the confidential nature of the information disclosed is a heavy one:92

The law . . requires that the proof should be of the most satisfactory and trustworthy kind. The onus of establishing a constructive trust lies upon him who seeks its enforcement and before a court of equity would be warranted in making a decree therefor, the evidence must be clear, unequivocal and decisive.

But once the existence of the confidential relationship and confidential information is established, the purloining of that information can be shown (and normally will only be shown) by circumstantial evidence:93

Such activities are sometimes not susceptible of direct proof in all their ramifications. Like a conspiracy, they may be established by circumstantial evidence. What might ordinarily be an innocent circumstance when isolated, may assume color and gignificance from what has been established by direct evidence. Reynolds v. Whitin Mach. Works, (CA-4) 167 F. 2d 78, text 82; Fleishhacker v. Blum, (CA-9) 109 F. 2d 543, text 546. It was thus put by the Supreme Court in Wager v. Hall 82 U.S. (16 Wall.) 584, 601, 21 L. Ed. 504, 506: 'All experience shows that positive proof of fraudulent acts ... is not generally to be expected, and it is for that reason, among others, that the law allows in such controversies a resort to circumstances as the means of ascertaining the truth, and the rule of evidence is well settled that circumstances altogether inconclusive, if separately considered, may, by their number and joint operation, especially when corroborated by moral coincidences, be sufficient to constitute conclusive proof. ....'

It can normally be anticipated that considerable groundwork will be necessary to gather the technical and other factual evidence necessary to prove a case. Rarely will the employee directly and openly violate the rule, 
particularly where the employer has published a prohibition against doing so. Normally there is resort to subterfuge and clandestine acquisition. In Shell $v$. Hunter, the case was established by a mass of data, maps, geophysical reports and dates of acquisition. All of these created a myriad of coincidence which, in the court's view, tipped the scales against the third party defendants: ${ }^{94}$

While some of these acquisitions, if found in circumstances more immaculate, might seem inherently innocuous, the sordid picture painted by this evidence as a whole imparts to them quite a different character.

Direct proof of fraudulent acts is not generally available. For this reason, in such controversies the rules of evidence permit resort to circumstantial evidence. If separately considered, the circumstances may be altogether inconclusive; but by their number and joint operation they may constitute conclusive proof. It seems to be unnecessary, therefore, for a plaintiff to establish every transaction with separate independent and isolated proof. It is enough that the circumstances taken as a whole constitute clear and convincing proof. In the Hunter case the court held that since it was so clearly established that the defendants were bent upon nefarious practices generally, a duty was cast upon them to exculpate themselves.

\section{(D) Limitations on the Extent of Accountability}

There are practical considerations which require a limitation on the extent of accountability. Consultants, in particular, often serve a plurality of masters and with closely related or the same subject matter. Without a test as to the remoteness of benefits, consultants would be placed under an impossible burden. This was observed by the Saskatchewan Court of Queen's Bench in Guyer Oil Company Ltd. v. Fulton: ${ }^{95}$

But it is not safe to make the attractive over-simplification of saying that a fiduciary must always account for all gains which come to him by reason of his fiduciary position.

The problem of establishing the limits of the rule was dealt with in Hanbury's Modern Equity (9th ed.) at 374:

But this still leaves open the question, to be determined on the facts of each case, whether the opportunity for profit arose by reason of the fiduciary position. For example, a solicitor or a stockbroker learns, in the course of his practice, of good opportunities for investment. Having satisfied the requirements of a particular client, is he precluded from making use of this information in respect of other trusts with which he is concerned? Or for himself? Similarly with the directors of several (non-competing companies? There is the danger that the rule, if applied inflexibly, may impose an impossible burden. As Lord Cohen said in Boardman v. Phipps, (1967) 2 A.C. 46 at 102-3; (1966) 3 All E.R. 721, see also Lord Upjohn at p. 126: '. . it does not necessarily follow that because an agent acquired information and opportunity while acting in a fiduciary capacity he is accountable to his principals for any profit that comes his way as the result of the use he makes of that information and opportunity. His liability to account must depend on the facts of the case.' Viscount Dilhorne, Ibid. at 90, quoted Lindley L.J. as saying 'to hold that a partner can never derive any personal benefit from information which he obtains from a partnership would be manifestly absurd' (1968), 34 L.Q.R. $472 \ldots$

Similar considerations arise in the case of joint ventures, where not every benefit, however remotely arising out of a partnership, is accountable. Thus an interest in a downstream fertilizer company was held by the Supreme Court of Canada not to be an accountable asset

94. Id. at 489.

95. (1973) 1 W.W.R. 97. 
between partners in a gas field. ${ }^{96}$ Rand J. delivered a minority judgment for two of the five judges who heard the case. He pressed for the full application of the rule "ruthlessly to prevent its corrosion by particular exceptions; by an absolute interdiction (to put) temptation beyond reach of the fiduciary by appropriating its fruits."97 It is interesting to speculate as to which side of the line the present Supreme Court would come down; its decision in the Pre-Cam ${ }^{98}$ case may be an indication.

\section{(E) In Camera Procedure}

While the general rule of the Anglo-American legal system is that all proceedings must be heard in open court one exception is found in actions involving trade secrets, where the court will order the case to be tried in camera.99 In Scott v. Scott, (1913) A.C. 417, Viscount Haldane L.C. said at 437:

... the exceptions are themselves the outcome of a yet more fundamental principle that the chief object of courts of justice must be to secure that justice is done. . . . The other case referred to, that of litigation as to a secret process, where the effect of publicity would be to destroy the subject-matter, illustrates a class which stands on a different footing. There it may well be that justice could not be done at all if it had to be done in public. As the paramount object must always be to do justice, the general rule as to publicity, after all only the means to an end, must accordingly yield.

The inherent jurisdiction of the court, acting in the interests of justice, would seem to permit the court to order the sealing of all documents, to order confidentiality as between counsel, and to designate special ways of dealing with the information before the court.

\section{(F) The Position of the Third Party}

It may be seen, then, that the court will protect trade secrets or confidential information improperly obtained, or divulged in breach of a confidential relationship. But what of the position of the third party who has, by fair means or foul, gained the knowledge of a trade secret?

Most of the English decisions have concerned actions against a defendant employee who, having received information from the plaintiff in confidence, consciously attempts to abuse, or does in fact abuse, that confidence for his own gain. In such cases the application of the equitable principle is relatively straightforward, and the courts have not hesitated to grant generous restitutionary relief, including an injunction and/or an account of profits or a quantum meruit award. But as against third parties, there are considerations which the court may take into account in determining whether an injunction should or should not be issued.

The position of the third party who consciously participates in the breach of confidence would seem to be clear. As a general rule the courts will have no hesitation in enjoining the dishonest defendant, any puppet company he controls and to which he has assigned confidential information, and any third party who consciously participated in a breach of confidence. The courts have uniformly applied the lash to him,

\footnotetext{
96. Midcon Oil and Gas Ltd. v. New British Dominion Oil Co. Ltd. (1956) 19 W.W.R. 317.

97. Id. at 341.

98. (1966) 56 W.W.R. 697 (S.C.C.). Professor Austin W. Scott, The Fiduciary Principle, (1949) 37 Cal. L.R. 539 at 541 puts the point as follows: "Some fiduciary relationships are undoubtedly more intense than others. The greater the independent authority to be exercised by the fiduciary, the greater the scope of his fiduciary duty. Thus, a trustee is under stricter duty of loyalty than is an agent upon whom limited authority is conferred or a corporate director who can act only as a member of the board of directors or a promoter acting for investors in a new corporation. All of these, however, are fiduciaries and are subject to the fiduciary principle of loyalty, although not to the same extent."

99. Williston \& Rolla, I The Law of Civil Procedure (1970) at 471.
} 
as with the defector; and the doctrine of constructive trust will compel him to disgorge to the injured plaintiff.

The Restatement on Restitution unhesitatingly sets forth the rule:100

Where a fiduciary in violation of his duty to the beneficiary communicates confidential information to a third person, if he had notice of the violation of duty, holds upon a constructive trust for the beneficiary any profit which he makes through the use of such information.

Such a situation arose in Ohio Oil Company v. Sharp.101 A geophysical company was hired to work for Ohio, and a structure was delineated. An employee of the geophysical company gave the results of the shooting to the defendant, who stepped in ahead of Ohio, blocked the area, drilled and brought in an oil field. Ohio sued to recover the leases, claiming that the geophysical information was a valuable property right, that its contract with the geophysical company stipulated that such information was the exclusive property of Ohio and was to be kept strictly confidential, and that the defendant wrongfully obtained the information from a member of the shooting crew, knowing that it was Ohio's exclusive property. The court held that the geophysical company and its employee occupied the same position of trust and confidence towards Ohio that Ohio's own employees occupied, and that a broad comprehensive trust relationship existed between the two. If the geophysical company or its employees had acquired the leases for their own use, the courts would have regarded the company or the employee as a constructive trustee of Ohio. Here an unfaithful employee violated the trust relationship, and turned this information over to a third party who obtained it with the knowledge that it was confidential and belonged to Ohio. Under such circumstances the defendant was held to be an accessory to the wrong that was committed, and was placed on the same footing as the employee of the geophysical company who gave him the information. Consequently, he was held to be a constructive trustee for Ohio in the acquisition of the leases. Again, the court held that it was unnecessary for Ohio to show either detriment, injury or damages in order to maintain its position.

But even in American law, it is submitted that a third party cannot claim the shelter and protection of bona fides, if he is reasonably put on inquiry as to the confidentiality of the information dealt off to him. These considerations were before the court in Cheuron v. Tapek:102

Furthermore, those who join with the primary wrongdoer in acquiring interests in the subject matter of the trust, because of actual or constructive knowledge of the facts under which the primary wrongdoer obtained knowledge of the subject matter of the trust, will likewise be held accountable to the rightful owner of the property. Thus, in this case those co-defendants ... who acquired their interests in these leases with actual or constructive knowledge of the circumstances under which Tlapek obtained his information with respect thereto, and of his acquisition of said leases are not entitled to hold their interests so acquired as against the plaintiff. Hunter v. Shell Oil Co., supra, at 488.

The Supreme Court of Arkansas and the Federal Courts applying the law of Arkansas have long been committed to the doctrine that notice of facts which put a man of ordinary intelligence or inquiry is equivalent to knowledge of all the facts that a reasonable inquiry would disclose. Trinity Royalty Company, Inc. v. Riggins, 199 Ark. 939, 136 S.W. 2d, 473; Waller v. Dansby, 145 Ark. 306; Walker-Lucas-Hudson Oil Company v. Hudson, 168 Ark. at 1107; and Reynolds, et al. v. Mosley, et al., 32 F. 2d, 979. The court finds, therefore, that all of said defendants hold their interests in said leases as constructive trustees for the plaintiff. 
Judicial dicta, and the Reporters of the Restatement of Torts, accept that a good faith purchaser who has no notice of any breach of confidence should be free to use and exploit confidential information even though he is subsequently told that it has been sold to him in breach of another's confidence.

Superficially this is an attractive conclusion, which preserves the certainty of commercial transactions. Bona fide purchase would certainly be a good defence if the plaintiff's action was based on the defendant's infringement of the plaintiffs s equitable property in the particular information. But it is questionable whether the mere payment of money should, in itself, defeat a restitutionary claim whose essence is a duty of good faith, a duty not to take unfair advantage of the plaintiff's confidence.

The observations of Lord Herschell in London Joint Stock Bank v. Simmons suggest that, in Anglo-Canadian law, even a bona fide third party purchaser receives no rights in a trade secret communicated to him by a wrongdoer: ${ }^{103}$

The general rule of the law is, that where a person has obtained the property of another from one who is dealing with it without the authority of the true owner, no title is acquired as against that owner, even though full value be given, and the property be taken in the belief that an unquestionable title thereto is being obtained, unless the person taking it can show that the true owner has so acted as to mislead him into the belief that the person dealing with the property had authority to do so. If this can be shown, a good title is acquired by personal estoppel against the true owner.

If a third party defendant has clearly acted in good faith and has changed his position to his detriment, the court may refuse to grant an injunction, even though he has acted foolishly in believing that he was not joining in breaching confidence. Such may have been Seager's case. ${ }^{104}$ In contrast, the court may enjoin, on terms, the honest defendant, even if he is a good-faith purchaser, if there is no evidence of any irrevocable change of position. ${ }^{105}$ As Lord Denning M.R. said in Fraser v. Evans 106 "even if (the defendant) comes by (the information) innocently, nevertheless, once he gets to know that it was originally given in confidence, he can be restrained from breaking that confidence." Presumably, from that point forward, constructive trust would also apply against the initially innocent, but now tainted, third party.

Where a third party induces an employee or former employee to commit a breach of contract that he has, either expressly or impliedly, made with his employer or former employer not to divulge secret or confidential information, such third party is liable to the employer in an action for damages for conspiracy to induce a breach of contract. ${ }^{107}$ Such an action lies even though no actual damages are proved. The essence of the action is that the employer is liable to sustain damages, and to have his common-law rights infringed, if the defendant persists in, and should be successful in, his efforts to obtain the confidential information he seeks.

The jurisdiction to restrain by injunction also enables the court to

103. [1892] A.C. 201 at 215.

104. [1967] 1 All E.R. 415 at 417.

105. Stevenson, Jordan \& Harrison Ltd. v. McDonald and Euans, (1951) 68 R.P.C. 190; (1952) 69 R.P.C. 10.

106. [1969] 1 All E.R. 8 at 11.

107. Garbutt Business College v. Henderson [1939] 3 W.W.R. 257. 
restrain a third party from using confidential information that has been obtained or communicated in breach of trust or in breach of contract. ${ }^{108}$

\section{CONCLUSION}

It would appear, therefore, that equity has evolved this rule, which is no longer founded in property or contract, but rather on the broad equitable principle of good faith: "He who has received information in confidence shall not take unfair advantage of it."

The on-going vigor of equity will continue to assure relief against cheaters, and the list is open. What may be unknown in the annals of industrial chicanery today may tomorrow engage the attention of the courts. The businessman of today must keep his eye on the ever-changing community conscience, lest he run afoul of the law and be made to disgorge profits which, in another day, would have been thought to be the just winnings of "sharp practice".

108. International Tools Led. v. Kollar, supra, n. 26. 